\title{
Age and growth of two populations of Pugilina cochlidium (Gastropoda: Melongenidae), from Thondi coast-Palk Bay in Tamil Nadu-South East coast of India
}

\author{
Patricio De los Ríos ${ }^{a, b}$ (D), Laksmanan Kanaguc (D), Chokkalingam Lathasumathic \\ and Chelladurai Stella** \\ aDepartamento de Ciencias Biológicas y Químicas, Facultad de Recursos Naturales, Universidad Católica de Temuco, \\ Casilla 15-D, Temuco, Chile. \\ bNúcleo de Estudios Ambientales, Universidad Católica de Temuco, Casilla 15-D, Temuco, Chile. \\ 'Department of Oceanography and Coastal Area Studies, Alagappa University, Thondi Campus-623409, Tamil Nadu, India. \\ *email: stella2004@rediffmail.com; stella2004@alagappauniversity.ac.in
}

Received: June 13, 2018 - Accepted: January 30, 2019 - Distributed: February 28, 2020

(With 4 figures)

\begin{abstract}
Age and growth of two populations of Pugilina cochlidium were studied. to address the lack of basic information on the growth rates and the size at sexual maturity of organism in a commercially harvested area, which will be important in considering the size limits to conserve this resources in future. In the present study the results showed more or less similar growth patterns in the males and females of two populations of Pugilina cochlidium. The age and growth estimation of these two populations of Pugilina cochlidium were completed using several methods and the outcome of one method will act as a check and control over the other using the FISAT 1 software. The values of asymptotic length $\left(\mathrm{L}_{\alpha)}\right.$ values obtained in the present study using various methods did not vary greatly. $\mathrm{L}_{\alpha}$ values obtained for the first population of Pugilina cochlidium was $95.55 \mathrm{~mm}$ for males and $106.05 \mathrm{~mm}$ for females and the growth rate $(\mathrm{K})$ for males $\left(0.588 \mathrm{yr}^{-1}\right)$ and females $\left(0.620 \mathrm{yr}^{-1}\right)$ was given by k-scan routine in ELEFAN. Similarly, the values of asymptotic length $\left(\mathrm{L}_{\alpha}\right)$, obtained for second population of Pugilina cochlidium, was $96.15 \mathrm{~mm}$ for males and $106.05 \mathrm{~mm}$ for females and the growth rate $(\mathrm{K})$ for males $\left(0.540 \mathrm{yr}^{-1}\right)$ and females $\left(0.950 \mathrm{yr}^{-1}\right)$ was given by $\mathrm{k}$-scan routine in ELEFAN.
\end{abstract}

Keywords: gastropods, Melongenidae, age, growth, Pugilina cochlidium.

\section{Idade e crescimento de duas populações de Pugilina cochlidium (Gastropoda: Melongenidae), de Thondi coast-Palk Bay na costa Tamil Nadu-Sudeste da Índia}

\begin{abstract}
Resumo
A idade e o crescimento de duas populações de Pugilina cochlidium foram estudados. abordar a falta de informações básicas sobre as taxas de crescimento e o tamanho na maturidade sexual do organismo em uma área comercialmente colhida, o que será importante considerando os limites de tamanho para conservar esses recursos no futuro. No presente estudo os resultados mostraram padrões de crescimento mais ou menos semelhantes nos machos e fêmeas de duas populações de Pugilina cochlidium. A idade e a estimativa de crescimento destas duas populações de Pugilina cochlidium foram completadas usando vários métodos e o resultado de um método funcionará como uma verificação e controle sobre o outro usando o software FISAT 1. Os valores de comprimento assintótico (L $\alpha$ ) obtidos no presente estudo usando vários métodos não variaram muito. Os valores de L $\alpha$ obtidos para a primeira população de Pugilina cochlidium foram de 95,55 mm para machos e 106,05 mm para fêmeas e a taxa de crescimento $(\mathrm{K})$ para machos $(0,588$ yr-1) e fêmeas $(0,620 \mathrm{yr}-1)$ foi dada pela rotina k-scan na ELEFAN. Similarmente, os valores de comprimento assintótico (L $\alpha)$, obtidos para a segunda população de Pugilina cochlidium, foram 96,15 mm para machos e 106,05 mm para fêmeas e a taxa de crescimento $(\mathrm{K})$ para machos $(0,540$ anos) e fêmeas $(0,950$ anos $)$. 1) foi dado pela rotina de k-scan na ELEFAN.
\end{abstract}

Palavras-chave: gastrópodes, Melongenidae, idade, crescimento, Pugilina cochlidium.

\section{Introduction}

The study of age and growth in mollusks; is of great importance for the biology and ecology of a species (Ismail et al., 2000; Ismail and Elkarmi, 2006; Eversole et al., 2008; Stella and Raghunathan,2008; Stella and Raghunathan, 2009). Age and growth of the animals are interrelated phenomena which denote the duration of life spent by the individual 
(age) and the increase in volume of mass (growth) during the corresponding period of life history. The distribution and habits of gastropods are influenced considerably by the environmental conditions which vary not only with latitude but also with habitat. In temperate molluscs the growth lines on the shell are valuable indicators of age, but in tropical waters, such variations in growth lines are not discernable. The age factors like height, weight and width of the shell and operculum in gastropods (Thivakaran, 1988). The habitat influence on the shape of the shell in marine gastropod have been studied by several researchers.

The literature of gastropods mentioned the study the growth and feeding of Hemifusus natanus in early crawling stage (Hamada, 1974). Thivakaran (1988) studied the population, age structure, growth and longevity of the gastropod in Littorinids Growth rate was studied was considered for different gastropods species such as Buccinum undatum (Gendron, 1992; Kideys, 1996), Busycon carica (Kraeuter et al., 1989; Castagna and Kraeuter, 1994; Avise et al., 2004), B. isaotakii (Ilano et al., 2004), Crepiduls fomicata (Collin, 1995), Drepanotrema kermatoides and D. climex (Rumi et al., 2004), Dropella cornus (Ismail et al., 2000), Pomacea sp., (Estebenet and Martin, 2000), Strombus gigas (Appeldoorn, 1988; Stoner et al., 2012). Finnally, Ravichandran (2012), tudied the age and growth of Chicoreus virgineus ponderosus and Siratus virgineus ponderosus (Gastropoda: Muricidae) in Thondi coast. For study growth study, one of the most applied tools is the software FISAT -1, that is based modeled following von Bertalanffy's growth function (VBGF), and L $\alpha$ estimation was obtained using Powell Whetherall plot (Gayanilo Junior et al., 1996).

Studies on age and growth also reveal that the age of sexual maturity and the age at which marketable size are attained of species Pugilinia cochlidium that is important in local fisheries in Thondi Coast India. The present investigation has also been undertaken to provide information on the grouping of the year classes, the dominant year groups, the environmental suitability and the fluctuations in the rate of growth.

\section{Materials and Methods}

\subsection{Specimens collection}

Random samples of Pugilina cochlidium (Linnaeus, 1758) populations were collected once in a month from trawlers of Thondi India coast for a period of one year (January 2009 to December 2009). The shells ( $n=40)$ were measured with the help of vernier caliper to the nearest $0.1 \mathrm{~mm}$. The method of determining growth and longevity in this study is by size frequency analysis of both shell length and weight. Data on shell length were arranged in size groups and plotted against percentage size frequencies. Growth rate was determined by employing Powel Wetherall, ELEFAN, Automatic scan and K-scan. Shell measurements: Length: The vertical distance from the apex to umbilical base of the shell is defined as length. Width: This is taken as the maximum dimension at right angles to the length of the shell in transverse plane. The length and width of the operculum was also measured. To find out weight, the soft parts were removed from the shell, blotted to remove the excess moisture and then weighed to the nearest $0.1 \mathrm{mg}$ using a single pan electric balance.

\subsection{Powell-Wetherall method}

Length frequency data were analyzed by Powell-Wetherall method, that is realist and robust for biological data (Powell, 1979; Wetherall, 1986) by identifying the smallest length predominating in the collections. This method is based on the following Equation 1 of Beverton and Holt (1956).

$\mathrm{Z}=\mathrm{K} \times\left\{\left(L_{\alpha_{-}} L_{\text {mean })} /\left(L_{\text {mean }}-L^{\prime}\right)\right\}\right.$

Where $L_{\text {mean }}$ is the mean length of organisms length $L$ ' and longer, while $L$ ' is "the length of all organisms of that length and longer vulnerable for collection". As $L$ ' can take any value equal to and above the smallest length which predominated the collections, equation can give a series of estimates of Z, one for each choice of $L$ '. This makes it possible to turn equation into a regression analysis with $L$, as independent variable. A series of algebraic manipulations shows that equation is equivalent to:

$L_{\text {mean }}-L^{\prime}=a+b^{*} L^{\prime}$

Where $\mathrm{Z} / \mathrm{K}=-(1+\mathrm{b}) / \mathrm{b}$ and $L_{\alpha}=-\mathrm{a} / \mathrm{b}$

Or $\mathrm{b}=-\mathrm{K} /(\mathrm{Z}+\mathrm{K})$ and

$\mathrm{a}=-\mathrm{b}^{*} L_{\alpha}$

Thus plotting $L_{\text {mean }}-L^{\prime}$ against $L$ ' gives a linear regression from which "a" (intercept) and b (slope) can be estimated and hence $L_{\alpha}$ and $\mathrm{Z} / \mathrm{K}$, of which equation represents the simplest approach. The asymptotic length $\left(L_{\alpha}\right)$ and the ratio of the coefficients of mortality and growth $(\mathrm{Z} / \mathrm{K})$ values were estimated by this method obtained from field works results.

\subsection{Ford-Waldford method}

This is a frequent method for estimate asymptotic length $\left(L_{\alpha}\right)$ and growth rate $(\mathrm{K})$, it is based in von Bertalanffy growth formula (Kimura, 1980), and its equation is:

$\mathrm{Lt}+1=\mathrm{a}+\mathrm{bLt}$

Where: $L_{\alpha}=\mathrm{a} /(1-\mathrm{b})$

$\mathrm{K}=-\ln \mathrm{b}$

All analysis were done using the software FISAT-1, and the subpackage ELEFAN-1, using the automatic search routine, response surface analysis and scan of ' $\mathrm{K}$ ' values, the best fitting curve was estimated (Gayanilo Junior et al., 1996).

\section{Results}

\subsection{Powell-Wetherall method: First population of Pugilin acochlidium - male (Table 1)}

Powell-Wetherall plots for the estimation of $\mathrm{L}_{\alpha}$ and $\mathrm{Z} / \mathrm{K}$ of which Equations 1 and 2 of males and females of the first population of Pugilina cochlidium are given in 
Figure 1. The $\mathrm{L}_{\alpha}$ values obtained for males and females of first population of Pugilina cochlidium were $98.71 \mathrm{~mm}$ $[\mathrm{r}=-0.987$; regression equation, $\mathrm{Y}=23.87+(-0.242) * \mathrm{X}]$ and $114.29 \mathrm{~mm}[\mathrm{r}=-0.979$; regression equation, $\mathrm{Y}=23.47$ $+(-0.205) * \mathrm{X}]$ respectively. The alignment of points on the straight line was quite satisfactory with a good coefficient of correlation (0.9056)

\subsection{Powell-Wetherall method: Second population of Pugilina cochlidium - male (Table 2)}

Powell-Wetherall plots for the estimation of $\mathrm{L}_{\alpha}$ and $\mathrm{Z} / \mathrm{K}$ of males and females of second population of Pugilina cochlidium are given in Figure 1. The $\mathrm{L}_{\alpha}$ values obtained for males and females of second population of
Pugilina cochlidium were $94.28 \mathrm{~mm}[\mathrm{r}=-0.993$; regression equation, $\left.\mathrm{Y}=22.09+(-0.21)^{*} \mathrm{X}\right]$ and $106.70 \mathrm{~mm}[\mathrm{r}=-0.99$; regression equation, $\mathrm{Y}=22.73+(-0.22) * \mathrm{X}]$ respectively. The alignment of points on the straight line were quite satisfactory with a good coefficient of correlation (0.06).

Estimation of growth parameters from length frequencies of first population of Pugilina cochlidium: The optimized growth parameters $\left(\mathrm{L}_{\infty}\right.$ and $\left.\mathrm{K}\right)$ and the goodness of fit index $(\mathrm{Rn})$ for the obtained growth parameters for males and females of First population of Pugilina cochlidium by ELEFAN I method in the FISAT II package are given in Table 3 and 4. The non-seasonalized length frequency histograms with growth curves for males and females of first population of Pugilina cochlidium are shown in
30.2 POWELL - WETHERALL PLOT

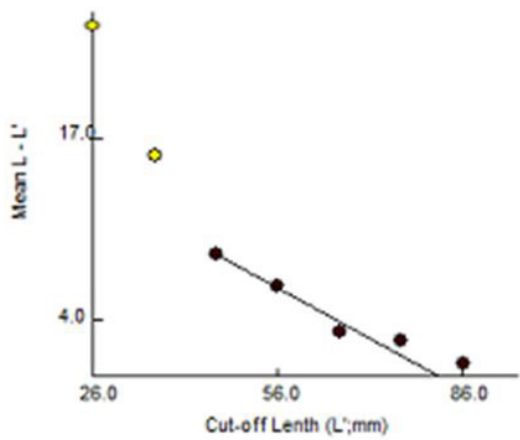

42.e POWELL - WETHERALL PLOT

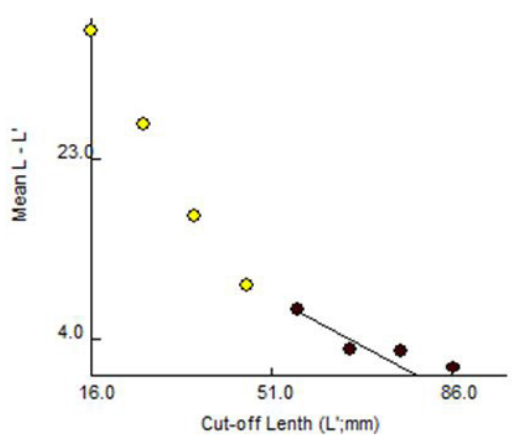

30.0 POWELL - WETHERALL PLOT

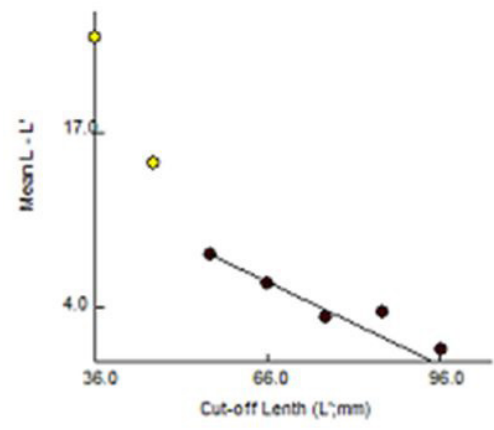

42.0. POWELL - WETHERALL PLOT

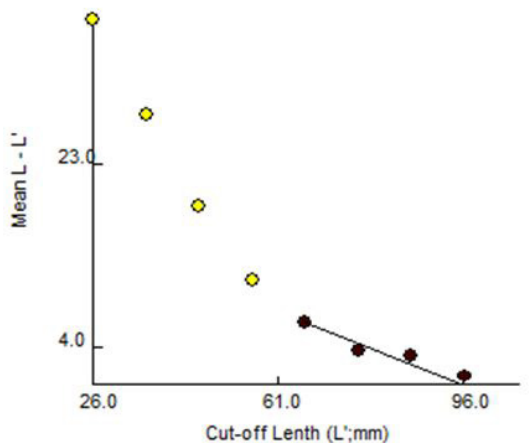

Figure 1. Powell-Wetherall plot first (up) and second (low) populations of Pugilina cochlidium - male (left) and female (right).

Table 1. Growth parameters of males and females of first population of Pugilina cochlidium obtained from different methods from length frequency data.

\begin{tabular}{lcccccc}
\hline \multicolumn{1}{c}{ Method } & Sex & $\mathbf{L} \infty \mathbf{( m m})$ & $\mathbf{Z} / \mathbf{K}$ & $\mathbf{K}\left(\mathbf{y r} \mathbf{r}^{\mathbf{1}}\right)$ & $\mathbf{t}_{\mathbf{0}} \mathbf{( \mathbf { y r } )}$ & $\mathbf{R n} / \mathbf{S c o r e}$ \\
\hline Powell wetherall & $\mathrm{M}$ & 98.71 & 3.13 & - & - & - \\
& $\mathrm{F}$ & 114.29 & 3.87 & - & - & - \\
ELEFAN i.Automatic scan & $\mathrm{M}$ & 95.55 & - & 1.0 & - & 0.16 \\
& $\mathrm{~F}$ & 106.05 & - & 1.0 & - & 0.16 \\
ELEFAN ii. K-scan & $\mathrm{M}$ & 95.55 & - & 0.588 & - & 0.18 \\
& $\mathrm{~F}$ & 106.05 & & 0.620 & & 0.18 \\
\hline
\end{tabular}


Figure 2. The results revealed that the $\mathrm{L}_{\alpha}$ and $\mathrm{K}$ values of $95.55 \mathrm{~mm}$ and $1.00 \mathrm{yr}^{-1}$ for males and $106.05 \mathrm{~mm}$ and $1.0 \mathrm{yr}^{-1}$ for females respectively, whereas, the K-scan routines gave the values of $95.55 \mathrm{~mm}$ and $0.58 \mathrm{yr}^{-1}$ for males and $106.50 \mathrm{~mm}$ and $0.62 \mathrm{yr}^{-1}$ for females respectively. The results of fitting growth parameters $\mathrm{L}_{\alpha}, \mathrm{K}$ and $\mathrm{t}_{0}$ to von Bertalanffy growth equation to obtain length at age are given in Table 5 and 6 for males and for females of first population of Pugilina cochlidium.

Estimation of growth parameters from length frequencies of second population of Pugilina cochlidium: the optimized growth parameters of which Equations $3 \mathrm{~L}$ and $\mathrm{K}$ ) and the goodness of fit index $(\mathrm{Rn})$ for the obtained growth parameters for males and females of second population of Pugilina
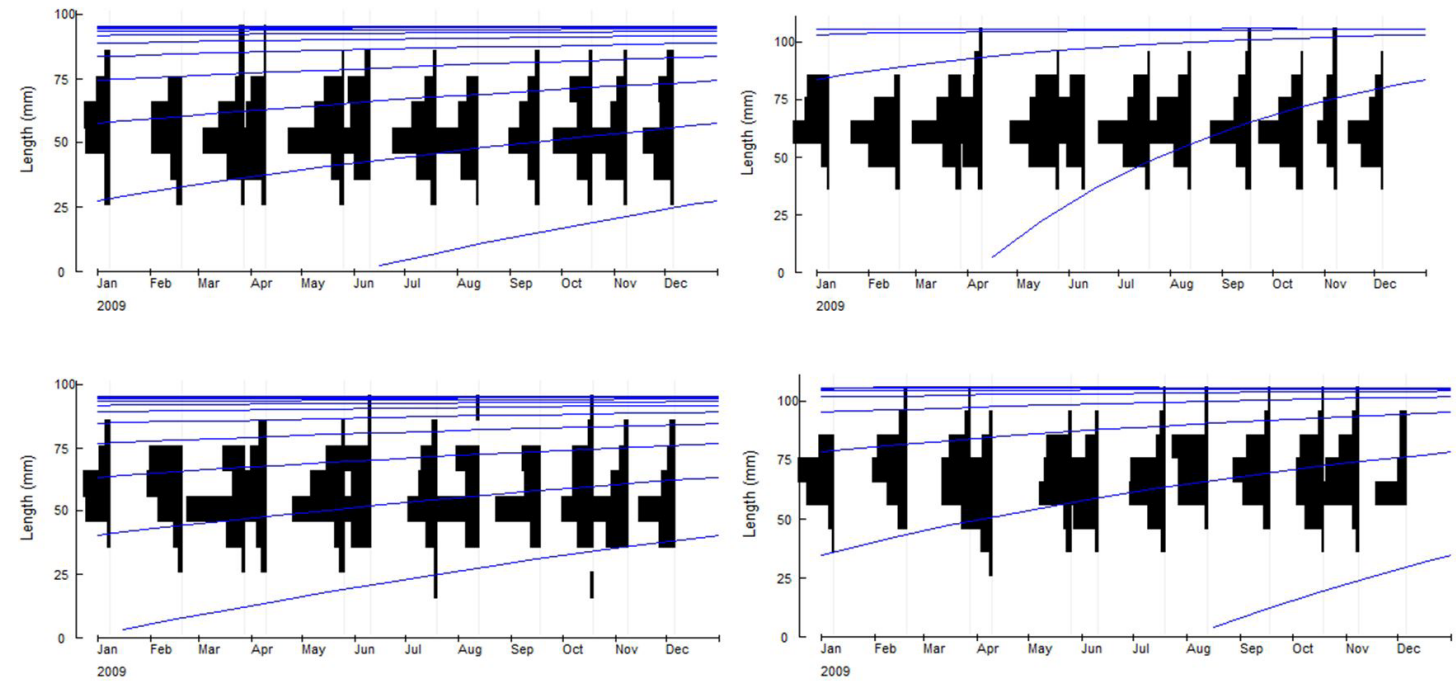

Figure 2. ELEFAN growth curve of first (up) and second (low) population of Pugilina cochlidium - male (up) and female (low).

Table 2. Growth parameters of males and females of second population of Pugilina cochlidium obtained from different methods from length frequency data.

\begin{tabular}{lcccccc}
\hline \multicolumn{1}{c}{ Method } & Sex & $\mathbf{L} \infty \mathbf{( m m})$ & $\mathbf{Z} / \mathbf{K}$ & $\mathbf{K}\left(\mathbf{y r} \mathbf{r}^{-1}\right)$ & $\mathbf{t}_{\mathbf{0}}$ (yr) & Rn/Score \\
\hline Powell wetherall & $\mathrm{M}$ & 92.74 & 2.38 & - & - & - \\
& $\mathrm{F}$ & 113.75 & 3.56 & - & - & - \\
ELEFAN i. Automatic scan & $\mathrm{M}$ & 96.15 & - & 1.00 & & 0.18 \\
& $\mathrm{~F}$ & 106.5 & - & 1.00 & & 0.26 \\
ELEFAN ii. K-scan & $\mathrm{M}$ & 95.55 & - & 0.54 & - & 0.22 \\
& $\mathrm{~F}$ & 106.05 & - & 0.95 & - & 0.23 \\
\hline
\end{tabular}

Table 3. Fitting of von Bertalanffy's growth equation of first population of Pugilina cochlidium-male.

\begin{tabular}{|c|c|c|c|c|c|}
\hline$t(y r)$ & t-to & $k(t-t o)$ & $\mathrm{e}^{-\mathrm{K}(\mathrm{t}-\mathrm{to})}$ & $1-\mathrm{e}^{-\mathrm{K}(\mathrm{t}-\mathrm{to})}$ & $\mathbf{L t}=\mathrm{L}_{\alpha}\left[1-\mathrm{e}^{-\mathrm{K}(\mathrm{t}-\mathrm{to})}\right]$ \\
\hline 1 & 1.83 & 1.06 & 0.34 & 0.65 & 62.49 \\
\hline 2 & 2.83 & 1.64 & 0.19 & 0.80 & 77.04 \\
\hline 3 & 3.83 & 2.22 & 0.10 & 0.89 & 85.19 \\
\hline 4 & 4.83 & 2.80 & 0.06 & 0.93 & 89.75 \\
\hline 5 & 5.83 & 3.38 & 0.03 & 0.96 & 92.31 \\
\hline
\end{tabular}

$\mathrm{L}_{\alpha}=95.55 \mathrm{~mm} ; \mathrm{K}=0.580 ; \mathrm{t}_{\mathrm{o}}=-0.831$

Table 4. Fitting of von Bertalanffy's growth equation of first population of Pugilina cochlidium -female.

\begin{tabular}{|c|c|c|c|c|c|}
\hline t (yr) & t-to & $k(t-t o)$ & $\mathrm{e}^{-\mathrm{K}(\mathrm{t}-\mathrm{to})}$ & $1-e^{-K(t-t o)}$ & $\mathbf{L t}=\mathbf{L}_{a}\left[1-\mathrm{e}^{-\mathrm{K}(\mathrm{t}-\mathrm{to})}\right]$ \\
\hline 1 & 1.62 & 1.00 & 0.36 & 0.63 & 67.21 \\
\hline 2 & 2.62 & 1.62 & 0.19 & 0.80 & 85.15 \\
\hline 3 & 3.63 & 2.24 & 0.10 & 0.89 & 94.81 \\
\hline
\end{tabular}

$\mathrm{L}_{\alpha}=106.05 \mathrm{~mm} ; \mathrm{K}=0.620 ; \mathrm{t}_{\mathrm{o}}=-0.558$ 
cochlidium Table2 by ELEFAN I method in the FISAT II package are given in Table 4. The non-seasonalized length frequency histograms with growth curves for males and females of second population of Pugilina cochlidium are shown in Figure 2, the automatic search routine in FISAT package derived the $\mathrm{L}_{\alpha}$ and $\mathrm{K}$ values of $96.15 \mathrm{~mm}$ and $1.00 \mathrm{yr}^{-1}$ for males and $106.5 \mathrm{~mm}$ and $1.00 \mathrm{yr}^{-1}$ for females respectively. Whereas, the $\mathrm{K}$-scan routines gave the values of $95.55 \mathrm{~mm}$ and $0.540 \mathrm{yr}^{-1}$ for males and $106.05 \mathrm{~mm}$ and $0.95 \mathrm{yr}^{-1}$ for females respectively. The results of fitting growth parameters $\mathrm{L}_{\alpha}, \mathrm{K}$ and $\mathrm{t}_{0}$ to von Bertalanffy growth equation to obtain length at age are given in Table 7 for males and Table 8 for females of second population of Pugilina cochlidium.

\subsection{Ford-Walford method}

The graphical depiction of $\mathrm{Lt}+1$ on $\mathrm{Lt}$ is shown in Figure 3 for females to estimate the asymptotic length. The regression line fitted to the points showed the following Equations 4 and 5 for males $y=1.23 x+69.65$ and $\mathrm{y}=13.80 \mathrm{x}+64.79$ for females. The functional regression slope, b', and intercept, a' were respectively 1.23 and 69.65 in the case of males and 12.8 and 64.79 in the case of females.

The $\mathrm{L}_{\alpha}$ values estimated by the Ford Walford method (95.55 $\mathrm{mm}$ for males and $106.05 \mathrm{~mm}$ for females) were used as input. The values of the regression coefficient a, obtained were 0.30 for males and 0.34 for females. The slope $b$, which is equal to the $\mathrm{K}$ value, was $0.58 \mathrm{yr}^{-1}$ for males and $0.62 \mathrm{yr}^{-1}$ for females. The ' $\mathrm{t}$ ' values estimated for males and females of first population of Pugilina cochlidium were $-0.83 \mathrm{yr}$ and $-0.55 \mathrm{yr}$ respectively.

\subsection{Estimation of growth parameters from length at age data}

The results of fitting growth parameters $\mathrm{L}_{\alpha}, \mathrm{K}$ and $\mathrm{t}_{0}$ to von Bertalanffy growth equation to obtain length at age are given in Table 7 for males and Table 8 for females of second population of Pugilina cochlidium.

Table 5. Estimation of $\mathrm{K}$ and $\mathrm{t}_{0}$ with the von Bertalanffy's plot of first population of Pugilina cochlidium -male.

\begin{tabular}{ccccc}
\hline Age & Length $(\mathbf{L t})$ & $\mathbf{L t} / \mathbf{L} \infty$ & $\mathbf{1 - L t} / \mathbf{L} \infty$ & $\mathbf{- L n}(\mathbf{1}-\mathbf{L t} / \mathbf{L} \infty)$ \\
\hline 1 & 28 & 0.29 & 0.70 & 0.34 \\
2 & 57 & 0.59 & 0.40 & 0.90 \\
3 & 74 & 0.77 & 0.22 & 1.48 \\
4 & 82 & 0.85 & 0.14 & 1.95 \\
5 & 90 & 0.94 & 0.05 & 2.84 \\
\hline
\end{tabular}

$\mathrm{K}=0.58, \mathrm{t} 0(-\mathrm{a} / \mathrm{b})=-0.83$.

Table 6. Estimation of $\mathrm{K}$ and $\mathrm{t}_{0}$ with the von Bertalanffy's plot of first population of Pugilina cochlidium-female.

\begin{tabular}{ccccc}
\hline Age & Length $(\mathbf{L t})$ & $\mathbf{L t} / \mathbf{L} \infty$ & $\mathbf{1 - L t} / \mathbf{L} \infty$ & $\mathbf{- L n}(\mathbf{1}-\mathbf{L t} / \mathbf{L} \infty)$ \\
\hline 1 & 46 & 0.433 & 0.56 & 0.56 \\
2 & 82 & 0.77 & 0.22 & 1.48 \\
3 & 103 & 0.97 & 0.02 & 3.54 \\
\hline
\end{tabular}

$\mathrm{K}=0.62, \mathrm{t} 0(-\mathrm{a} / \mathrm{b})=-0.55$.

Table 7. Fitting of von Bertalanffy's growth equation of male of second population of Pugilina cochlidium.

\begin{tabular}{|c|c|c|c|c|c|}
\hline t (yr) & t-to & $k(t-t o)$ & $\mathrm{e}^{-\mathrm{K}(\mathrm{t}-\mathrm{t})}$ & $1-\mathrm{e}^{-\mathrm{K}(\mathrm{t}-\mathrm{to})}$ & $\mathbf{L t}=\mathbf{L}_{\alpha}\left[1-\mathrm{e}^{-\mathrm{K}(\mathrm{t}-\mathrm{to})}\right]$ \\
\hline 1 & 1.64 & 0.88 & 0.41 & 0.58 & 56.26 \\
\hline 2 & 2.64 & 1.42 & 0.36 & 0.63 & 60.24 \\
\hline 3 & 3.64 & 1.96 & 0.21 & 0.78 & 74.56 \\
\hline 4 & 4.64 & 2.50 & 0.08 & 0.91 & 87.78 \\
\hline 5 & 5.64 & 3.04 & 0.47 & 0.95 & 91.02 \\
\hline 6 & 6.64 & 3.58 & 0.02 & 0.97 & 92.91 \\
\hline
\end{tabular}

$\mathrm{L}_{\alpha}=95.55 \mathrm{~mm} ; \mathrm{K}=0.540 ; \mathrm{t}_{\mathrm{o}}=-0.646$

Table 8. Fitting of von Bertalanffy's growth equation of female of second population of Pugilina cochlidium.

\begin{tabular}{|c|c|c|c|c|c|}
\hline t (yr) & t-to & $k(t-t o)$ & $\mathrm{e}^{-\mathrm{K}(\mathrm{t}-\mathrm{to})}$ & $1-\mathrm{e}^{-\mathrm{K}(\mathrm{t}-\mathrm{to})}$ & $\mathbf{L t}=\mathbf{L}_{a}\left[1-\mathrm{e}^{-\mathrm{K}(\mathrm{t}-\mathrm{to})}\right]$ \\
\hline 1 & 1.83 & 1.22 & 0.29 & 0.70 & 74.95 \\
\hline 2 & 2.83 & 1.89 & 0.15 & 0.85 & 90.14 \\
\hline 3 & 3.83 & 2.56 & 0.07 & 0.92 & 97.91 \\
\hline 4 & 4.83 & 3.23 & 0.03 & 0.96 & 101.89 \\
\hline
\end{tabular}

$\mathrm{L}_{\alpha}=105.05 \mathrm{~mm} ; \mathrm{K}=0.670 ; \mathrm{t}_{\mathrm{o}}=-0.831$. 


\subsection{Von Bertalanffy plot}

The results of von Bertalanffy plot for the estimation of Equations 4 and $5 \mathrm{~K}$ and $\mathrm{t}_{0}$ for males and females of first population are presented shown in Tables 5 and 6 whereas second population of Pugilina cochlidium are shown in Tables 9 and 10 and are graphically depicted in Figures 3 and 4. The $\mathrm{L}_{\alpha}$ values estimated by the Ford Walford method $(95.55 \mathrm{~mm}$ for males and $106.05 \mathrm{~mm}$ for females) were used as input. The values of the regression coefficient a, obtained were 0.34 for males and 0.55 for females. The slope $b$, which is equal to the $\mathrm{K}$ value, was
$0.54 \mathrm{yr}^{-1}$ for males and $0.67 \mathrm{yr}^{-1}$ for females. The ' $\mathrm{t}$, values estimated for males and females of second population of Pugilina cochlidium were $-0.64 \mathrm{yr}$ and -0.83 yr respectively.

\subsection{Ford-Walford plot}

The graphical depiction of $\mathrm{Lt}+1$ on $\mathrm{Lt}$ is shown in Figures 3 and 4 for females to estimate the asymptotic length. The regression line fitted to the points showed the following Equation 4 for males $y=0.82 x+58.24$ and $y=8.85 x+79.07$ for females. The functional regression slope, b', and intercept, a' were respectively 0.82 and 58.24 in the case of males and 8.85 and 79.07 in the case of females.
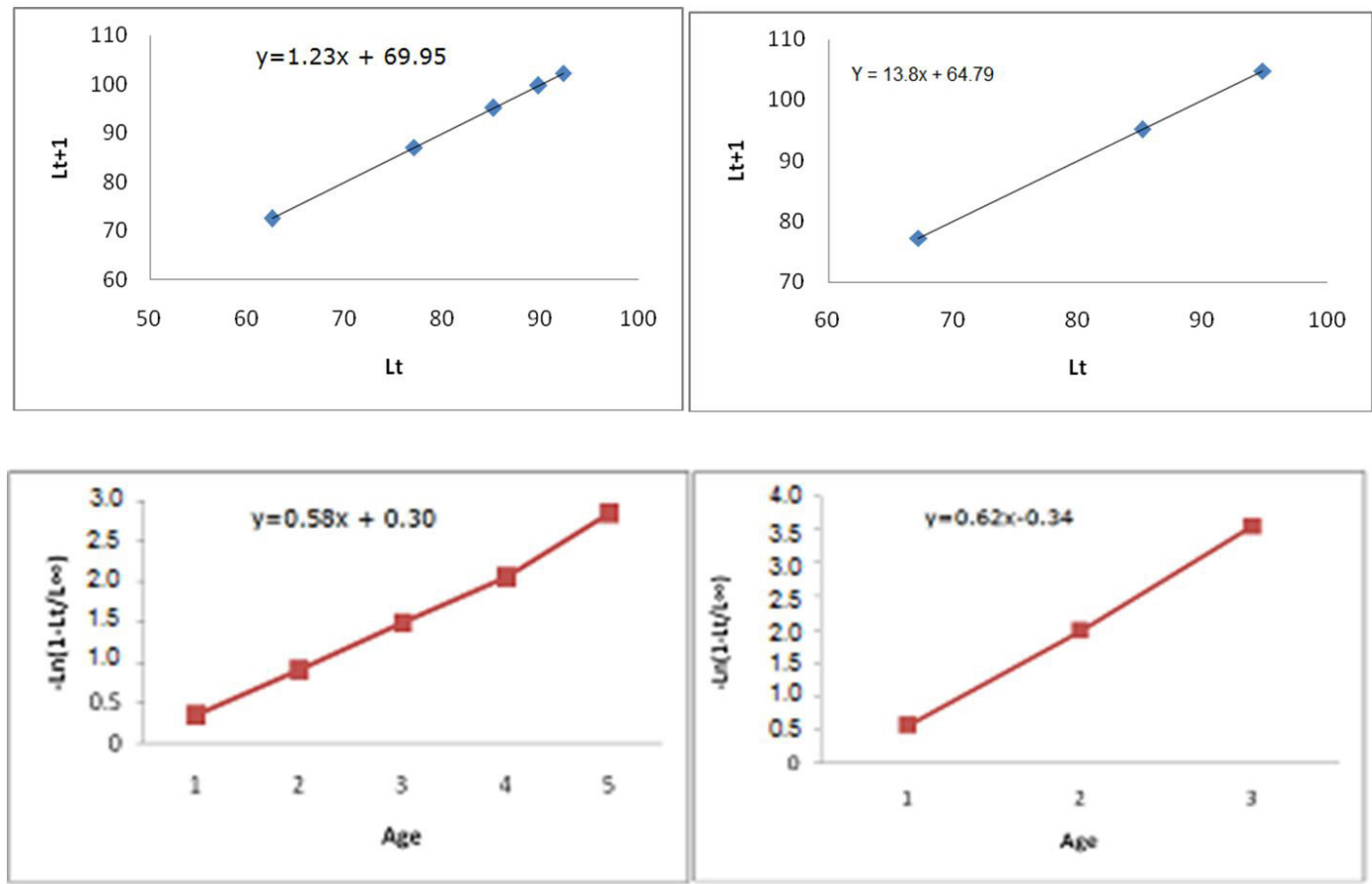

Figure 3. Ford-Walford (up) and von Bertalanffy's (low) plot of first population of Pugilina cochlidium -male (left) and female (right).

Table 9. Estimation of $\mathrm{K}$ and $\mathrm{t}$ with the von Bertalanffy's plot for male Pugilina erecta.

\begin{tabular}{|c|c|c|c|c|}
\hline Age & Length (Lt) & $\mathbf{L t} / \mathbf{L} \infty$ & $1-\mathrm{Lt} / \mathrm{L} \infty$ & $-\operatorname{Ln}(1-\operatorname{Lt} / \mathbf{L} \infty)$ \\
\hline 1 & 25 & 0.26 & 0.73 & 0.30 \\
\hline 2 & 42 & 0.43 & 0.56 & 0.57 \\
\hline 3 & 64 & 0.66 & 0.33 & 1.10 \\
\hline 4 & 78 & 0.81 & 0.18 & 1.69 \\
\hline 5 & 86 & 0.90 & 0.09 & 2.30 \\
\hline 6 & 92 & 0.96 & 0.03 & 3.29 \\
\hline
\end{tabular}

$\mathrm{k}=\mathrm{b}=0.540, \mathrm{t}_{0}=(-\mathrm{a} / \mathrm{b})=-0.646$.

Table 10. Estimation of $\mathrm{K}$ and $\mathrm{t}_{0}$ with the von Bertalanffy's plot for female Pugilina erecta.

\begin{tabular}{ccccc}
\hline Age & Length $(\mathbf{L t})$ & $\mathbf{L t} / \mathbf{L} \infty$ & $\mathbf{1 - L t} / \mathbf{L} \infty$ & $\mathbf{- L n}(\mathbf{1 - \mathbf { L t }} / \mathbf{L} \infty)$ \\
\hline 1 & 45 & 0.42 & 0.57 & 0.55 \\
2 & 78 & 0.73 & 0.26 & 1.32 \\
3 & 90 & 0.84 & 0.15 & 1.88 \\
4 & 103 & 0.97 & 0.02 & 3.54 \\
\hline
\end{tabular}

$\mathrm{k}-\mathrm{b}=0.670,(-\mathrm{a} / \mathrm{b})-0.831$. 

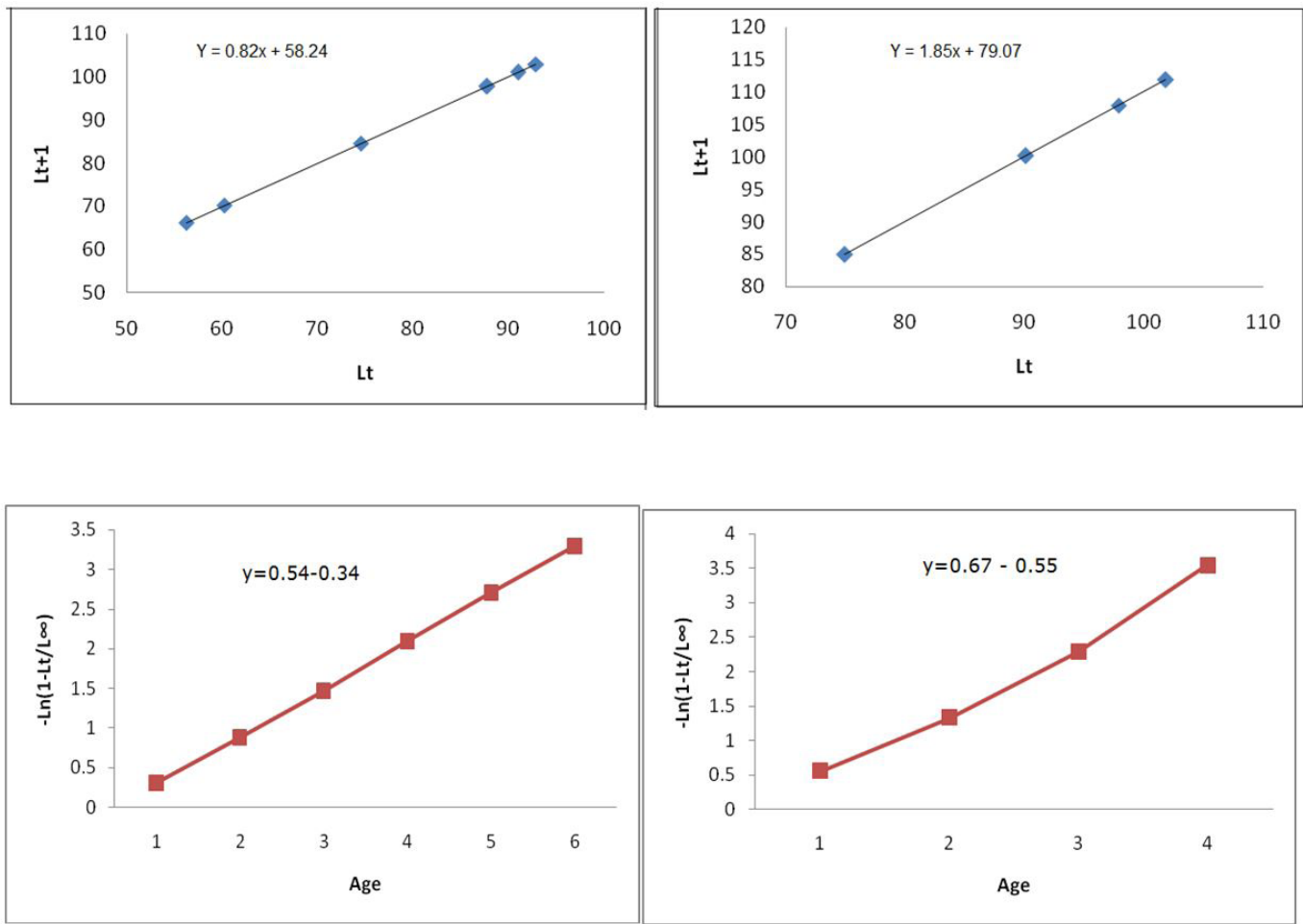

Figure 4. Ford-Walford (up) and von Bertalanffy's (low) plot of second population of Pugilina cochlidium -male (left) and female (right).

\section{Discussion}

An initial estimate of $\mathrm{L} \alpha$ was obtained using Powell Wetherall plot. This length frequency data was run on ELEFAN - 1 sub package available in FISAT using the automatic search routine, response surface analysis and scan of ' $\mathrm{K}$ ' values and the best fitting curve was estimated. The determination of age and growth based on a single method has its own limitations especially when the determination of age and growth is through indirect methods. The values of asymptotic length $\left(\mathrm{L}_{\alpha}\right)$ obtained for first population of Pugilina cochlidium were $95.55 \mathrm{~mm}$ for males and $106.05 \mathrm{~mm}$ for females and the growth rate $(\mathrm{K})$ for males $\left(0.588 \mathrm{yr}^{-1}\right)$ and females $\left(0.620 \mathrm{yr}^{-1}\right)$ were given by $\mathrm{k}$-scan routine in ELEFAN. Similarly the values of asymptotic length $\left(\mathrm{L}_{\alpha}\right)$ obtained for second population of Pugilina cochlidium were $96.15 \mathrm{~mm}$ for males and $106.05 \mathrm{~mm}$ for females and the growth rate $(\mathrm{K})$ for males $\left(0.540 \mathrm{yr}^{-1}\right)$ and females $\left(0.950 \mathrm{yr}^{-1}\right)$ were given by k-scan routine in ELEFAN, nevertheless it would be necessary include data of other populations for a robust estimation. Several investigators, both in tropical and temperate waters, have found that growth pattern was not uniform throughout the year and in the early stage, growth rate is faster than the later part (Rajagopal, 1982; Kamala, 1983; Kanakasabai, 1985). Various factors are known to influence growth (Wilbur and Owen,1964). In some gastropods, such as Nerita fulguarans, $N$. peloronta and $N$. Versicolor, growth was found to be slow during winter but rapid during summer, parallel with the seasonal changes in Littorina spp. (Kolipinski, 1964). From tropical and temperate waters, exhibited remarkable variations in growth, size and life span. Moore (1937) has recorded a maximum growth of $27.5 \mathrm{~mm}$ with a life span of 4-5 years for in L. littence and a life span of 5-6 years and a maximum height of $18.5 \mathrm{~mm}$ in L. sukatilis (Moretean 1976). Stella et al. (1992) recorded in Chicoreus ramosus have attained a length of 107.7, 163.7, 205.0, and 235.3 in the $1^{\text {st }}, 2^{\text {nd }}, 3^{\text {rd }}, 4^{\text {th }}$ year respectively. This species was found to have a life span of 4-5 years. In the present investigation, the species were found to have a life span of more than 4 years. This increased growth rate of these species may be due to increased food availability and the combined effect of hydro biological factors in their habitat. Besides, that it is presumed that the northeast monsoon is said to have considerable influence on the growth rate of this gastropod (Ravichandran, 2012).

In addition to that the pressure of a longer fishing season in offshore areas, as well as, the intensification of harvesting of inshore stocks could be detrimental to the gastropod resource propagation if the stocks are presently fished beyond their maximum sustainable yield. There is little information on the population dynamics of these gastropods are found along the coast of Thondi to allow for the sound management decisions regarding the sustainability of the fishery. Gastropod resources are practices to include the retention of all species, regardless of size, which is conducive to over-harvesting 


\section{Acknowledgements}

The present study was founded by project MECESUP UCT 0804, and the authors express their gratitude to M.I. and S.M.A. for their valuable suggestions and comments. The authors express their thankfulness to the financial support for this research work under RUSA-Phase 2.0 scheme, Govt of India.

\section{References}

APPELDOORN, R., 1988. Age determination, growth, mortality and age of first reproduction in adult Queen Conch, Strombus gigas L., off Puerto Rico. Fisheries Research, vol. 6, no. 4, pp. 363-378. http://dx.doi.org/10.1016/0165-7836(88)90005-7.

AVISE, J., POWER, A. and WALKER, D., 2004. Genetic sex determination, gender identification, and pseudohermaphroditism in the knobbed whelk, Busycon carica (Mollusca: Melongenidae). Proceedings. Biological Sciences, vol. 271, no. 1539, pp. 641646. http://dx.doi.org/10.1098/rspb.2003.2533. PMid:15156923.

BEVERTON, R. and HOLT, S., 1956. A review of methods for estimating mortality rates in exploited fish populations, with special reference to sources of bias in catch sampling. Conseillntitutel'Exploration de la Mer, vol. 140, pp. 67-83.

CASTAGNA, M. and KRAEUTER, J.N., 1994. Age, growthrate, sexual dimorphism and fecundity of knobbed whelk Busycon carica (Gmelin, 1791) in a western mid-Atlantic lagoon system, Virginia. Journal of Shellfish Research, vol. 13, pp. 581-585.

COLLIN, R., 1995. Sex, size, and position: a test of models predicting size at sex change in the protandous gastropod Crepidulafomicata. American Naturalist, vol. 146, no. 6, pp. 815-831. http://dx.doi.org/10.1086/285826.

ESTEBENET, A.L. and MARTIN, P.R., 2000. Inter-and intrapopulation variation in growth patterns of Pomacea canaliculata (Gastropoda: Ampullariidae). In: VI International Congress on Medical and Applied Malacology 2000, Havanna. Cuba.

EVERSOLE, A.G., ANDERSON, W.D. and ISELY, J.J., 2008. Age and growth of the knobbed whelk Busycon carica (Gmelin 1791) in South Carolina subtidal waters. Journal of Shellfish Research, vol. 27, no. 2, pp. 423-426. http://dx.doi.org/10.2983/07308000(2008)27[423:AAGOTK]2.0.CO;2.

GAYANILO JUNIOR, F.C., SPARRE, P., and PAULY, D., 1996. FAO-ICLARM Stock assessment tools, (FiSAT) user's manual. FAO Computation Informatics Series Fisheries. vol. 7, pp. 1-126.

GENDRON, L., 1992. Determination of the size at sexual maturity of the waved whelk Buccinum undatum in the Gulf of St. Lawrence as a basis for the establishment of a minimum catchable size. Journal of Shellfish Research, vol. 11, pp. 1-7.

HAMADA, S., 1974. Growth and feeding of Hemifususnatanus in early crawling stage. Venus, vol. 33, pp. 75-79.

ILANO, A.S., ITO, A., FUJINAGA, K. and NAKAO, S., 2004. Age determination of Buccinumis aotakii (Gastropoda: Buccinidae) from the growth striae on operculum and growth under laboratory conditions. Aquaculture, vol. 242, no. 1/4, pp. 181-195. http:// dx.doi.org/10.1016/j.aquaculture.2004.03.028.

ISMAIL, N.S. and ELKARMI, A.Z., 2006. Age, growth and shell morphometrics of the Gastropod Monodontadama (Neritidae: Prosobranchia) from Azraq Oasis, Jordan. Pakistan Journal of
Biological Sciences, vol. 9, no. 3, pp. 549-552. http://dx.doi. org/10.3923/pjbs.2006.549.552.

ISMAIL, N.S., ELKARMI, A.Z. and AL-MOGHRABI, S.M., 2000. Studies on the population structure and shell morphometrics of the coral livorous gastropods Drupellacornus in the Gulf of Aqaba, Red Sea. Indian Journal of Marine Sciences, vol. 29, pp. 165-170.

KAMALA, B., 1983. Studies on some aspects of the biology of the top shell Euchelus asper (Gmelin) (Gastropoda: Prosobranchia) of the Palm Beach shingles of the Visakhapatnam coast. Waltair: Andhra University, 120 p. Ph.D. Thesis.

KANAKASABAI, R., 1985. Studies on some neritids (Archaeogastropods: Mollusca) from the Vellarcoleroon estuarine complex (South East Coast of India). Chidambaram: Annamalai University, 120 p. Ph.D. Thesis.

KIDEYS, A.E., 1996. Determination of age and growth of Buccinum undatum (Gastropoda) off Douglas, Isle of Man. Institute of marine sciences, middle east technical university, Turkey. Helgoländer Meeresuntersuchungen, vol. 50, no. 3, pp. 353-368. http://dx.doi.org/10.1007/BF02367109.

KIMURA, D.K., 1980. Likelihood methods for the von Bertalanffy growth curve. Fish Bulletin, vol. 77, pp. 765-776.

KOLIPINSKI, M.C., 1964. The life history, growth and ecology of four intertital gastropods. (Genus: Nerita) of South east Florida. Miami: University of Miami, 130 p. Ph.D. Thesis.

KRAEUTER, J.N., CASTAGNA, M.A. and BISKER, R., 1989. Growth rate estimates for Busycon carica (Gmelin, 1791) in Virginia. Journal of Shellfish Research, vol. 8, pp. 219-225.

MOORE, H.B., 1937. The biology of Littorina littorea. Part I. Growth of shell and tissues, spawning, length of life and mortality. Journal of Marine Biology Assocciation United Kingdom, vol. 21, no. 02, pp. 721-742. http://dx.doi.org/10.1017/S0025315400053844.

MORETEAN, J., 1976. Study on the growth and life spawn of Littorina saxatilis (Olovi) rudis (Maton). Cahiers de Biologie Marine, vol. 17, pp. 463-484.

POWELL, D.G., 1979. Estimation of mortality and growth parameters from the length frequency of a catch. Rapp. Rapports et Proces-Verbaux des Reunions - Conseil International pour L'Exploration de la Mer, vol. 175, pp. 167-169.

RAJAGOPAL, S., 1982. Studies on the intertital mollusk Umbonium vestiarium (Archeogastropoda. Trochidae: Umbonidae) of the South east coast of India. Chidambaram: Annamalai University, 82 p. Ph.D. Thesis.

RAVICHANDRAN, S., 2012. Taxonomy and Biology of Chicoreus species (Class: Bivalvia: Family: Muricidae) from Thondi coast - Palk Bay in Tamil Nadu. Kairakudi: Alagappa University, $120 \mathrm{p}$. PhD Thesis.

RUMI, A., GREGORIC, D.E. and ROCHE, M.A., 2007. Growth rate fitting using the von Bertalanffy model: analysis of natural populations of Drepanotrema spp. snails (Gastropoda: Planorbidae). Revista de Biología Tropical, vol. 55, no. 2, pp. 559-567. http:// dx.doi.org/10.15517/rbt.v55i2.6031.PMid:19069766.

RUMI, A., GUTIERREZ, D., ROCHE, M. and TASSARA, M., 2004. Population structure in Drepanotremakermatoides and D. cimex (Gastropoda: Planorbidae) in natural conditions. Malacologia, vol. 45, pp. 453-458.

STELlA, C. and RAGHUNATHAN, C., 2008. Lengthweight and allometric relationship in Chicoreus virgineus and 
Muricanthusvirgineus (Gastropoda: Muricidae) distributed in Cuddalore coast of Bay of Bengal. Journal of Nature Environment Pollution and Technology, vol. 7, no. 2, pp. 359-364.

STELLA, C. and RAGHUNATHAN, C., 2009. New records of Muricanthuskuesterianus (Tapparone-Carefri 1875) Family: Muricidae, from Palk Strait, South East Coast of India. Journal of Nature Environment and Pollution Technology, vol. 8, no. 1, pp. 63-68.

STELLA, C., RAJKUMAR, T. and AYYAKKANNU, K., 1992. Analysis of size class distributions of Chicoreus ramosus collected from the Gulf of Manner area, South East Coast of India. Phuket Marine Biology Center Special Publication, vol. 11, pp. 91-93.

STONER, A.W., MUELLER, K.W., BROWN-PETERSON, N.J., DAVIS, M.H. and BOOKER, C.J., 2012. Maturation and age in queen conch (Strombusgigas): urgent need for changes in harvest criteria. Fisheries Research, vol. 131-133, pp. 76-84. http://dx.doi.org/10.1016/j.fishres.2012.07.017.

THIVAKARAN, G.A., 1988. Studies on Littorinids Littorina quadricentus (Philippi) and Nodilittorina pyramidalis Guoy and GaiMord, 1883), (Gastropoda: Prosobranchia) from Tranquebar rocky shore, south-east coast of India. Chidambaram: Annamalai University, 100 p. Ph.D. Thesis.

WETHERALL, A., 1986. A new method for estimating growth and mortality parameters from length-frequency data. Fishbyte, vol. 41, pp. 12-14.

WILBUR, K.M. and OWEN, G., 1964. Growth. In: K.M. WILBUR and C.M. YONGE, eds. Physiology of Mollusca. New York: Academic Press, vol. 1, pp. 211-242.http://dx.doi.org/10.1016/ B978-1-4832-3241-6.50013-5. 